\title{
Karthik Ramanna*
}

\section{Thin Political Markets in Accounting and Beyond: Lessons for Leadership Education}

https://doi.org/10.1515/ael-2017-0011

Published online October 3, 2017

\begin{abstract}
Thin political markets are regulatory processes characterised by two features: first, a concentrated commercial interest that is also the source of necessary experiential expertise; second, low participation from the general interest driven by low issue salience. Thin political markets generate capture in two ways distinct from the classic collective-action scenario: first, that the nature of necessary expertise is tacit or implicit -- knowledge that comes from doing; second, that the issues at stake evince little interest from the general public or its intermediaries such as the media or politicians. The challenge in thin political markets is that business leaders, who are the subject-matter experts, are both the source of capture and the only realistic prospect for solution. I discuss ways in which we can address this challenge.
\end{abstract}

Keywords: political economy, public policy, accounting, political process

\section{Accounting Regulation and the Public Good}

1. "Why and How EFRAG was Reformed" by Philippe Maystadt, https://doi.org/10.1515/ael2017-0010

2. "A Speech on "Why Accounting Matters: A Central Bank Perspective"” by Claudia Schwarz, https://doi.org/10.1515/ael-2017-0012

3. "Thin Political Markets in Accounting and Beyond: Lessons for Leadership Education" by Karthik Ramanna, https://doi.org/10.1515/ael-2017-0011

4. "Financial Regulation for a Better Society" by Shyam Sunder, https://doi.org/10.1515/ael2017-0013

5. "Open Debate on Accounting Regulation and the Public Good" by Imke Graeff, https://doi. org/10.1515/ael-2017-0023

Article Note: These remarks were made when the author was at Harvard Business School.

*Corresponding author: Karthik Ramanna, Harvard Business School and University of Oxford, Oxford, United Kingdom of Great Britain and Northern Ireland, E-mail: Karthik.ramanna@bsg.ox.ac.uk 
Thank you very much, my name is Karthik Ramanna, and I am a professor at Harvard Business School. I am delighted to be here, and I am going to share with you some of my work that is come out of a conceptual understanding of the political process in accounting. This is an area that I have been studying for some time now. Eleven years ago I was a first-year graduate student in a $\mathrm{PhD}$ program in accounting, and as part of that graduate program I had to write a first year summer paper. I decided to write the paper on a topic that would marry my interests, which were in political economy and public policy, with my then nascent career in accounting. I chose as a topic what was then a relatively recent but also a very controversial issue: US GAAP accounting rules for mergers and acquisition, which is known as FAS-141 and 142. In the eleven year since, a substantial fraction of my work has focused on the intersection of accounting and the political process.

What I am going to talk about today is, stepping back from this work, what are some common themes that have emerged across my studies. The focus of my talk today is actually the subject of a book that will be published this October by the University of Chicago Press: The book is called Political Standards. ${ }^{1}$ Now, as is likely to be the case with any body of work that spans over a decade, a lot of the details that are necessary to making a robust argument in this context will not be part of this talk. I am happy to take questions if we have time at the end, but I am just going to give you a very broad flavour at this stage. I also want to acknowledge that the book is based on a number of academic articles, ${ }^{2}$ published in peer-reviewed journals, including the one that Mr Shyam Sunder and Mr Yuri Biondi edit. ${ }^{3}$ Copies of this journal - I believe - are out back. The book is also based on a number of Harvard Business School case studies that I have written: The cases focus on the political process in accounting in various countries. And so, obviously, I owe a large debt to a lot of co-authors and individuals who along the way have helped foster or nurture these arguments.

I have studied the political process in many different contexts, including - as I eluded to - mergers and acquisitions in the United States, also foreign-currency translations, fair-value accounting more broadly, and

1 Ramanna, Karthik (2015), Political Standards: Corporate Interest, Ideology, and Leadership in the Shaping of Accounting Rules for the Market Economy, Chicago, IL: University of Chicago Press, Chicago, IL.

2 See, for example, Ramanna, Karthik (2015), Thin Political Markets: The Soft Underbelly of Capitalism, California Management Review, vol. 57, no. 2, pp. 5-19.

3 Accounting, Economics and Law - A Convivium, Ed. by Avi-Yonah, Reuven S. / Biondi, Yuri / Sunder, Shyam; de Gruyter. 
related-party transactions. I have also studied the political process in many jurisdictions beyond the US: In China, in India, here in the European Union, and in Britain in particular. And across all of these studies of the political process in accounting, three themes in particular have emerged as salient. First, on any given issue there is somewhere between five and fifty people in the world that truly understand the specifics of that issue. And not surprisingly perhaps, those people, those subject-matter experts, are the ones that have the most concentrated commercial interest in the outcome of that particular regulation. The second finding is perhaps not very surprising given the first, which is that the rules of the game that emerge from this political process are subtly, but in various significant ways, favouring those experts that fully understand the issue at hand. And the third finding, which is just as important, is that there is no unequivocal villain in the story: There is no one firm, or organisation, or institution, or group that you can point to and say, "Ah! That is the problem." In part because nobody is really an expert on everything, and so what happens is different people show up when the subject matter at hand is something they truly understand, they truly care about. And in those contexts they shape the rules, but in other contexts there are perhaps unaware or they do not care as much, and so they are absent from the process. So the political process that emerges in an area like accounting is better characterised as a quilt of special interests rather than as an unequivocal special interest or group that is dominating the process. And these three findings collectively characterise this phenomenon that I refer to as 'thin political markets'. I want to spend a little time just exploring what I mean by thin political markets and maybe very briefly give you an example of what might constitute a thin political market in accounting, and then talk about what we can do to solve this problem.

Thin political markets, at the very basic level, are characterised by two forces: On the one hand, you have got a concentrated commercial interest that is collocated with experiential expertise; and, on the other hand, you have a low participation from the general interest. And that low participation is driven in part by low-issue salience. Now, if you look at these two characteristics quickly, particularly the idea that you have a concentrated commercial interest on the one hand and a diffuse general interest on the other, this reflects the classic collective-action problem that political scientists have been studying for almost fifty years at this point. And on one level the notion of thin political markets that characterises the nature of accounting very much does represent a version of this collective-action problem. But we have gotten fairly good in terms of political science and public policy at trying to solve the collective-action problem. In fact, a number of recent books by political scientists and business historians such David Moss and Gunnar Trumbull have suggested that just 
simply having the condition where you have got a concentrated commercial interest and diffuse participation by the general interest is not sufficient to precipitate what economists call regulatory capture, and that capture is often over-diagnosed in these circumstances. And I happen to agree that this might in fact be the case. What is a distinctive characteristic about the nature of the political process in accounting is one that I will explain in a moment, one that shows how a thin political market might be distinct from the classic collectiveaction problem.

What makes a thin political market, which characterises the accounting process, different or distinct? Well, for one, the idea that the concentrated commercial interest is co-located with experiential expertise. This is to say that the nature of expertise that is necessary to adjudicate political processes in the context of something like accounting is such that expertise is what we call tacit; the knowledge that is necessary is tacit. It is not the kind of knowledge one gains from a textbook, it is not the kind of knowledge you know - Professor Shyam Sunder and I as academics might be able to expound in the context of a classroom. It is knowledge that comes from doing, it is knowledge that comes from being engaged in the practice of business: So, if you are thinking about accounting for mergers and acquisitions for example, it is the knowledge that comes from investment banks, and audit firms, that are in the practice of engaging in these transaction on a dayto-day basis. That experiential knowledge matters hugely in the context of something like accounting.

The other thing that is direct or distinct in the context of accounting is this notion of low-issue salience. When you are thinking about participation by the general interest, on some matters, for example, on matters such as social security reform or universal healthcare in the United States, these are issue where the general interest might have relatively low individual stakes as compared to a special interest at large. But at the same time they care about the issue at a level that it is salient in their minds, at a level which even if they were at a cocktail party, they would discuss the issues. This creates incentives for intermediary organisation such as elected politicians or the media to represent the general interest in the political process. When you think about the classic collective-action problem, a lot of intermediaries such as elected politicians in representative democracies or the media might surface to represent the general interest in a way that mitigates the likelihood of capture. The nature of the problem with something like accounting rules is, it is boring. So, most people do not go to cocktail parties where they hear vibrant chatter about the state of accounting rules. I am someone who has spent the last eleven years of my life studying the political process there, and if I am in a cocktail party the last thing I 
want to do is tell someone that this is what I study. Because then people quickly clear away from me! In that context when you have an issue that has very low issue salience, how do you create incentives for intermediaries? Or how do you create a system or institutions to represent the general interest in this context? This is a fundamental challenge in thin political markets, and this what characterises the problem of thin political markets.

Now, as I have already eluded to several times, I happen to think that accounting rule making is a thin political market. In part, I have structured this idea of thin political markets through an inductive study of the accounting rule making process. But I would like to point that accounting is not the only thin political market out there: Rulemaking for auditing, rulemaking for actuarial standards, rulemaking for the insurance industry, rulemaking for bank governance and how things like tier-one capital are set are all thin political markets. So thin political markets in effect would characterise a number of different very important regulatory processes in a capital market economy that are outside of the salience of the general public.

One question that I often get asked, although probably not from this audience that is deeply engaged in accounting issues, is: "Okay, so there might be regulatory capture or the threat of regulatory capture in a thin political market, but should we really care? Do accounting rules really matter in the grand scheme of things?" Certainly there is a whole bunch of evidence that seems to suggest that accounting rules have a real impact in the allocation of capital or scarce resources across competing ventures in a capital market economy. There is a lot of evidence, but in the interest of time, I am going to skip over that evidence. In a nutshell, we know the real impact accounting has on things like GDP and resources allocation and wealth distribution. Similarly, actuarial standards matter, bank governance standards matter, insurance standards matter in an economy; factors that are determined in thin political markets do matter for our society.

The challenge or the paradox of thin political markets is that business leaders or managers, who are the subject matter experts in this context, are really behaving in ways that on one level fundamentally represent what is characterised or understood as their 'social responsibility'. That is, when these experts arrive at the regulatory table, they behave in a way that represents the interest of the corporation that they serve. So, if I am an investment banker showing up at a meeting that is discussing what mergers and acquisition accounting rules should look like, I tend to take the perspective that represents the best interest of my firm and the investment banking industry. And if I am an audit partner, I take the perspective that represents the best interest of my audit firm. And so people are 
acting in a way that Milton Friedman characterised as the "social responsibility of business", which is, in his words, "to increase profits".

But Friedman was very careful to point out that this maxim, this principle, is subject to the constraint, to the condition that we are acting "within the rules of the game." What we are dealing with when we are talking about setting accounting rules is designing the rules of the game. So, what is the social responsibility of business leaders in the context of setting the rules of the game? Is it legitimate to manipulate the definition of profit - which is what you do when you change an accounting rule opportunistically - in the spirit of increasing profits? These are the kind of questions that I would like us to consider; consider whether there are limits to the profit-seeking motive and the way we approach profit seeking in the theory of market capitalism.

When I talk about this challenge of the social responsibility of business, I want to highlight maybe a couple of examples of what I mean by this, or maybe just one example in the interest of time. And I will give you an example from IFRS since this is an audience that is intimately familiar with IFRS. A few years ago, the People's Republic of China was in the process of converging, or harmonising, its local accounting rules with IFRS. This harmonisation process was driven in large part by the desire of Chinese manufacturing firms to have IFRS-compliant cost data, which was necessary in the adjudication of lawsuits on 'dumping' of foreign products. Let me explain: China is a manufacturing economy, and it exports its products to developed economies such as the EU and the US. Chinese products in these markets are very competitive because they are priced low. Chinese manufacturers argue that this is because they have low costs. US and EU manufacturers argue that this is because Chinese companies are 'dumping' their products at below cost (funded by state subsidies). To defend themselves against dumping lawsuits, Chinese manufacturers point to the cost data in the financial statements. But there is lots of concern about the quality of those financial statements. China is a 'non-market economy' according to its World Trade Organisation accession protocols, which means that financial statements of Chinese companies are not necessarily admissible in foreign courts. One way around this is for Chinese companies - and the Chinese economy at large - to embrace IFRS-based financial statements. But because a large part of the Chinese economy is characterised by state owned enterprises, and these state-owned or state-controlled enterprises have intimate relations with each other, there were concerns about what would happen on related party disclosures if China adopted IFRS. The Chinese state-controlled enterprises argued that if they were to adopt the extant IFRS standard on related party disclosure, they would end up having to disclose thousands of pages of text about their interconnectedness, which on the one hand might be a good 
thing because it would shed some light on the economics of these businesses. But from a compliance cost perspective these firms argued vigorously against such disclosures. The IASB at the time was reeling from the United States' reluctance to converge with IFRS and was looking for a big win. China was at the time the next biggest thing to the US, and the IASB was very keen to bring China on board. One of the key issues, or one of the key clauses that the statecontrolled enterprises in China brought to the table as part of the terms of negotiation to China's IFRS harmonisation was the revisiting of worldwide standards for related party disclosures for state-controlled enterprises. This is how we ended up, in part, changing the IFRS disclosure requirements on state control enterprises.

I currently teach a course on leadership at Harvard Business School, before I taught that course I used to teach the required accounting course, and in the required accounting course on the very first day we would introduce the notion of related party transactions: If you do not have disclosure of related party transactions, the very integrity of financial report is compromised; you do not know if you have taken money from your left pocket and put it in your right pocket. If you think about it, related party disclosures are fundamental to the integrity of accounting. The fact that as part of a country's convergence to IFRS, something as fundamental as the worldwide standard on related party disclosure could have been changed is testimony to the power of special interests in thin political markets

I have given you one example but there are numerous examples from a host of different countries. But the bottom line is the power of special interests in thin political markets to shape our day-to-day lives - through the integrity of financial reports, one can have an enormous impact on the integrity of capital markets and therefore on our ability to be able to save effectively for the future and our ability to invest in productive ventures in the future. There are all of these repercussions from these narrow special interests initiatives that emerge from very small groups of individuals shaping the rules of the game. What do we do about this? How do we resolve this?

Last year, I was reading this book called Flash boys by Michael Lewis, who is a journalist, and he was writing about the world of high frequency trading, which is where trading happens at level of nanoseconds in financial markets. There was a particular individual who was in the business of high frequency trading who realised that the way the rules of high frequency trading had been set up was such that only a handful of the very largest players could benefit and all of us as individual investors we are losing in the process. And here is what that individual, his name is Brad Katsuyama, says: "It feels like I am an expert in something bad that badly needs to be changed. I think there are only a few 
people in the world that can do anything about it. If I do not do anything about it right now, me Brad Katsuyama, there is no one to call." This quote characterises the issue or the challenge of thin political markets, going back to this at idea that there are a very few experts, a handful of experts, who shape the rules of the game. And in those moments when they sit across the table determining what the rules are, they can have these Brad Katsuyama moments: How should they respond?

This is where I take off my hat as a researcher and I put on my hat as a professor, and I actually profess. I would argue that in this context we need to fundamentally revisit or to reimagine what is the capitalist contract? What is it that we in business schools, we as academics in business schools, teach business leaders about their responsibilities when it comes to setting up the rules of the game. This is not a problem that can be solved by creating new regulatory agencies. This is not a problem that can be solved by trying to periodically get the media to pay attention. Because the solution lies with those who have the experiential knowledge, the business leaders who have the subject matter background that is necessary to adjudicate this process. We have to reorient their perspective; we have to reorient how it is they view their responsibilities when it comes to setting up the rules of the game.

I am going to stop there in the interest of time and turn it over to Professor Shyam Sunder, and then take questions at the very end if there is time.

Acknowledgements: This article was prepared for and read at the international workshop on "Which accounting regulation for Europe's economy and society?" organised under the auspices of the European Parliament in Strasbourg, on 20 May 2015, in tribute to Mr Jérôme Haas (1963 - 20014), first chairman of the Accounting Standards Authority of France (ANC).

Funding: This article was organised by the Laboratory of Excellence on Financial Regulation (Labex ReFi), which is supported by PRES heSam under the reference ANR-10-LABX-0095. It benefitted from a French government grant by the National Research Agency (ANR) under the funding program 'Investissements d'Avenir Paris Nouveaux Mondes (Investments for the future Paris - New Worlds) reference ANR-11-IDEX-0006-02. 